\title{
Biochemical and histopathological studies on the influence of aqueous extract of fenugreek seed (Trigonella foenum graecum) on alloxan diabetic male rats.
}

\author{
Enas A. M. Khalil \\ National Organization For Drug Control And Research
}

\section{Abstract}

Diabetes and the related complications continue to be a major medical problem in Egypt. In spite of the warning of adaptation for regime diet, practicing exercise and administering hypoglycaemic drugs.

The toxic side effects, contraindication and sometimes diminutions in response after prolonged use of antidiabetic drugs encouraged to search for therapeutic herbal remedies for safety, efficacy and economy . Diabetes is manifested by multiple disturbances in the metabolic processes of the body, which are attributed to an insufficient supply of insulin. Many plants were known for their activity as antidiabetic agents

This investigation aims to clarify the role of fenugreek seed aqueous extract in its therapeutic dose on beta cells number, blood glucose and plasma insulin levels in alloxan diabetic rats. Also to illustrate the functional biochemical changes and the associated histopathological alternations in pancreas, liver, kidney, aorta and testes as influenced by fenugreek and alloxan induced diabetes for 4-weeks of treatment.

24 adult male albino rats were divided into four groups, control, diabetic, diabetic rats treated with $0.1 \mathrm{mg} / \mathrm{kg} \mathrm{B.W}$. of fenugreek seed aqueous extract and $0.1 \mathrm{mg} / \mathrm{kgB} . \mathrm{W}$. fenugreek treated group for 4-weeks. The results indicated that, in the diabetic state significant increase in plasma glucose accompanied by significant reduction in plasma insulin and beta cells number. Significant increase in serum AST, ALT and ALP associated with dilatation and severe congestion of central vein and sinusoids, vacuolization and necrotic areas. Inflammatory area around portal tract. Significant increase in serum urea and creatinine accompanied by atrophy of most glomerular tuft, others displaying swelling and hyperemia. Diffuse extravagations of red blood cell between the degenerated renal tubules. Dilatation and severe congestion of blood vessels. Dilated convoluted tubules, contain hyaline casts in their lumens were observed. Significant increase in serum total cholesterol and triglycerides accompanied by degenerative changes in aorta and formation of medial calcinosis in some cases, significant decrease in serum testosterone levels associated by germ cells depletion as well as sloughing and degeneration of sperms.

In conclusion, fenugreek seeds exhibited antioxidant property could ameliorate the alternations induced in diabetes.

This investigation recommended that higher concentrations of debitterized fenugreek seeds may double the regeneration of beta -cells in pancreas, further studies would be done in mammals.

Fenugreek seed aqueous extract exhibited antioxidant property which ameliorated the biochemical and histopathological alternation induced by alloxan.

In conclusion, higher concentrations of debitterized fenugreek seeds can regenerate beta cells in pancreas; further studies would be done in mammals.

\section{Introduction}

Fenugreek-El Helba- (Trigonella Foenum Graecum) L.[Fam.Fabaceae]. It used for thousands of years to reduce blood sugar, increase lactation, stomach ulcers, appetite loss, Fever, catarrh of the respiratory tract, bronchitis, pellagra and eczema (Blumenthal et al,2000).

Many studies have shown that the fenugreek seeds exhibit anti diabetic action (Sharma et al,1996), hypolipidaemic effect 
(Sharma, et al,1996),hypocholesterolemic effect(Al-Habori and Raman 1998) \& (Thompson and Ernst, 2003), antitumor activity (Sur, et al, 2001), antiulcer property (Pandian et al, 2002), immunomodulatory effects (Bin-Hafeez et al, 2003) and lactation induction (Tiran, 2003).

Feungreek seed contains 45-60\% carbohydrates, mainly mucilaginous fiber (galactomannans); 20-30 proteins high in lysine and tryptophan, 5-10\% fixed oils (lipids),pyridine-type alkaloids mostly trigonelline $(0.2-0.36 \%)$, choline $(0.5 \%)$, gentianine, and carpaine, flavonoids ,free amino acids, calcium and iron ,saponins, glycosides, cholesterol and sitosterol, vitamins $\mathrm{A} 1, \mathrm{~B} 2, \mathrm{~B} 3, \mathrm{~B}, \mathrm{C}$ and $\mathrm{D}$, nicotinic acid and volatile oils (Blumenthal et al, 2000, and Shang et al,1998).

Diabetes is a common chronic disease of man race is manifested by multiple disturbances in the metabolic processes of the body, which are directly attributed to an insufficient supply of insulin.

This investigation aims to clarify the role of fenugreek seed aqueous extract in its human therapeutic dose on beta cells number, blood glucose and plasma insulin levels in alloxan diabetic rats. As well as to illustrate the functional biochemical changes and the associated histopathological alternations in pancreas, liver, kidney, aorta and testes as influenced by fenugreek and alloxan for 4-weeks of treatment.

\section{Materials and Methods Plant material}

Fenugreek seeds were obtained from local market, cleaned of extraneous matter and ground into a fine powder $.200 \mathrm{ml}$ boiling distilled water were added to $2.5 \mathrm{gm}$ powder fenugreek seed, left it for 10 minutes and filtered .The filtrate was dried at $35-45 \mathrm{C} \dot{\circ}$ in incubator.

\section{Animals}

Male albino rats weighing $120 \pm 10$ gm bodyweights were purchased from Helwan Farm.

The animals were kept at the room temperature of $25 \pm 5 \mathrm{C} \bullet$ with a natural lighting cycle (12) hours . They were kept under observation for about two weeks before the initiation of the experiment.

Diabetes were induced in overnight fasted animals by a single subcutaneous injection of alloxan monohydrate (Sigma USA). In a dose of $120 \mathrm{mg} / \mathrm{kg} \mathrm{Bwt}$.

Dissolved in acetate buffer immediately prepared before usage. Seven days after injection of alloxan blood glucose levels of all surviving rats were determined. Only rats with glucose levels above $200 \mathrm{mg} / \mathrm{ml}$ were considered diabetic and employed for the assay.

\section{Experimental design}

Twenty -four adult male albino rats weighing (110-130gm). They divided into four groups 6 each. Group I, represented control, group II diabetic rats, group III diabetic rats treated with $0.1 \mathrm{mg}$ of fenugreek seed aqueous extract and group IV treated with $0.1 \mathrm{mg}$ of fenugreek extract, that dose equivalent to human therapeutic dose (Paget and Barnes, 1964) daily for 4 weeks.

\section{Blood Sampling}

Blood samples were collected from retro-orbital vein in three separate tubes, one tube with EDTA for determination of haematological parameter .Red blood cells (RBCs) and (WBCs) were counted in Neubarer Hemocytomter. The second tube containing potassium oxalate and sodium fluoride for estimation of glucose (Trinder,1969) and insulin . The third containing the blood was allowed to clot at room temperature and the serum obtained after centrifugation was used for determination serum aspartate amino transferase (AST), alanine amino transeferase (ALT) (Reitman and Frankle,1957), alkaline phosphtase (ALP) ( German Society for clinical chemistry,1972 ) ,urea (Tabacco et al,1979) ,creatinine (Bartles et al,1971) ,total cholesterol (Allain et al., 1974), Triglycerides (Bucolo and David,1973), total protein (Doumas,1975), albumin (Doumas et al. ,1971), and globulins were calculated as the difference between total protein and albumin. Insulin and testosterone were estimated by Kits obtained from IMX Abbott Labs, IL/USA. 


\section{Histological examination}

Fresh liver, kidney, aorta and pancreas samples were collcted in formol saline. Testes were collected in Bouin' fluid. All samples were stained with H\&E. Some sections of pancreas were fixed with modified aldehyde -Fuchsine (M.A.F.) (Kiernan, 1999).

\section{Statistical analysis}

All data obtained were analyzed using student 't'-test according to (Sendecor and Coebram ,1969).

\section{Results and Discussion}

Diabetes is manifested by multiple disturbance in the metabolic processes of the body, which are directly attributed to an insufficient supply of insulin. This investigation aims to clarify the role of fenugreek seed aqueous extract in its human therapeutic dose on beta cell numbers, blood glucose and plasma insulin levels in alloxan diabetic rats. As well as to illustrate the functional biochemical changes and the associated histopathological alternations in pancreas, liver, kidney, aorta and testes as influenced by fenugreek and alloxan induced diabetes for 4-weeks of treatment.

A decrease in rat body weight was noted in alloxan -induced diabetic rats for 4-weeks in comparison with control (table 1). A significant decline in rat body weights treated with alloxan (Joy and Kuttan, 1999), and streptozotocin (Bwititi et al, 2000). Alloxan a cytoxic agent affect organs and metabolism which lead to significant decline in the growth rate. But when the diabetic rats treated with fenugreek seed aqueous extract, the decrease in body weight was nearly suppressed after 4weeks. Fenugreek extract treated rats showed non-significant increase in body weight over the experimental period.

Fenugreek aqueous extract exhibited antioxidant property (Thirunavukkarasu et al ., 2003), which protects the functional organs and increase body weight

Table (1) displayed lower blood parameters of the diabetic rats against the control values The red blood cells were significantly decreased after 30 days in diabetic rats due to the increase in lipid peroxidation of the erythrocyte cell membrane and destruction of red blood cells (anemia) (Kang-Xin et al ,1990). Reduction in haemoglobin concentration is considered as useful indicator for lower number of red blood cells.

Non-significant change of white blood cell at 4-weeks by alloxan treatment was detected Rats treated by fenugreek extract displayed non-significant variation from the corresponding control after month in RBCs, $\mathrm{Hb} \%$ and in WBCs. Fenugreek treated diabetic displayed non-significant alternation in $\mathrm{RBCs}, \mathrm{Hb} \%$ and in WBCs comparable to control (table 1) .

The anti-oxidant property of fenugreek (Thirunavukkarasu etal, 2003), inhibit lipid peroxidation of the erythrocytes. Fenugreek contains iron (Blumenthal et al ,2000), it can improve anemia conditions .

Plasma glucose levels were significantly elevated in alloxan diabetic rats and this was associated with low plasma insulin concentration (table1).This result was due the cytotoxic agent alloxan which cause a massive reduction of the $\beta$ cells of the islets of langerhans in pancreas of diabetic rats comparable to control (figs. $1 \& 1$ a) .Also severe $\beta$-cells necrosis and intracellular vacuolation were observed (figs. 2 \& 2a), which induced hyperglycemia. Diabetic animals treated with fenugreek extract had lower blood glucose and this was accompanied by an increase in plasma insulin concentration (table1) .The number of $\beta$-cells relatively increased ,the islets appeared more organized and less vacuolated (figs. $3 \&$ 3a). Fenugreek extract treated rats(figs. 4 \& 4a)displayed lower blood glucose and increase insulin level. The hypoglycemic effect of fenugreek extract may be due to the major existence of 4- isohydroxy leucine which stimulates insulin secretion from pancreas (Al-Habori and Raman 1998) \& (Haefele et al,1997). Sharma et al (1996) recorded that 100gm of fenugreek debitterized powdered seeds for 10 days significantly reduced blood sugar for type I diabetes .It may be due to the regeneration $\beta$ cells number. Puri et al, (2002) reported that hypoglycemic effect 
of fenugreek may be mediated through stimulating insulin synthesis and /or increasing secretion $\beta$ pancreatic cells of langerhans.

In the diabetic non -treated rats (table 1) serum aspartate aminotransferase, alanine aminotransferase and alkaline phosphatase increased significantly compared to their corresponding control .The augmentation in these enzymes may be due to the hepatotoxic effect of alloxan or may be a result following hepatic necrosis (Tanak et al, 1988 and Cornelius,1989). Also liver obtained various pathological changes in comparison with control(fig.4) were dilatation and severe congestion of central veins and sinusoids necrotic areas of hepatocytes (figs.4a \& 4b ). Inflammatory area around portal tract was observed (fig.4c). Diabetic rats treated with fenugreek displayed significant decrease in Serum AST, ALT and ALP (table 1). Liver showed amelioration in histological pattern (fig.5). Fenugreek extract treated rats showed non significant increase in serum AST, ALT and ALP (table1). Liver displayed nearly normal architecture (fig.6). Bin-Hafeez et al, (2003) observed that, no elevation in liver function enzymes by fenugreek treatment. As well as (Duke, 1985) \& (Kapoor,1990)recorded that fenugreek has no inflammatory disorder in liver

Significant increase in urea and creatinine was observed in diabetic rats (table 2), which attributed to increased protein catabolism (Finco, 1984) and to glomerular or tubular destructive changes (Ravel, 1984). The pathology of kidney appeared as dilatation and severe congestion of blood vessels (fiq.10), Majority of convoluted tubules cloudy swelling, contained hyaline cast in their lumen and vacuolar degenerative changes were observed in some renal tubules (fiq.10c). Diffuse extravagations of red blood cells between the degenerated renal tubules (fiq.10). The glomerular tuft were congested, atrophied (fq.10a) and some of them were swollen(fiq10b). In fenugreek treated diabetes significant decrease was noticed in urea and creatinine levels .An improvement in kidney structure occurred (fiq.11). The involvement of free radicals in alloxan nephrotoxicity may be normalize by fenugreek (Ravikumar and Anuradha 1999). fenugreek treated rats, showing normal appearance in kidney (fiq.12)

The analysis of data showed marked increase in serum total cholesterol and triglycerides (table,2) which accompanied by degenerative changes of aorta (fiq.14) and in some cases formation of medial calcinosis (Fiq.14a )in diabetic rats comparable to control ones (fiq.13).

Atherosclerosis is a diabetes macrovascular complication, which account for most of mortality in diabetic population (king, et al.,1990). Fenugreek treated diabetic rats significantly reduced serum total cholesterol and triglycerides (table,2) and prevented degenerative changes in aorta and atherosclerosis (Fiq.15). In rats treated with fenugreek aorta revealed normal pattern (fiq.16).

Fenugreek contains lecithin which dissolve cholesterol and contains lipotropic (fat dissolving ) substances , which dissolves deposits of fat , prevents fatty accumulates and water retention (Blumenthal et al. , 1998) . Al-Habori and Raman (1998) reported that fenugreek hypocholesterolemic effect has been attributed to increased conversion of hepatic cholesterol to bile salts due to loss, of complexes of these substances ,in the feces, with fenugreek fiber and saponins.

Serum total protein and albumin was significantly reduced in diabetic rats comparable to control ones (table1). The decrease in serum total protein was due to a reduction in ribosomal protein synthesis as a result of insulin deficiency (Jefferson et al., 1983). The decrease of serum albumin and the increase in globulin level (table 2) was another confirmation of liver damage (Kanko, 1989). In diabetic rats treated with Fenugreek, serum total protein and albumin levels restored to normal values (table 2). This result was due to fenugreek antioxidant property which improves organ functions (Devasena and Menon, 2002 \& Thirunavukkarasu et al, 2003). Rats treated with Fenugreek recorded non-significant increase in serum total protein, albumin and globulin compared with the control ones. 
Alloxan induced diabetes in male rats significantly lowered serum testosterone level. Also the testis of diabetic animals showed inactive seminiferous tubules, characterized by focal disorganization of germ cells (fiq.18) in comparison with control (fiq 17). The testis has been described to be a sensitive target for diabetic complications (Tarleton et al., 1990 \& Gondos and Bevier, 1995). Fenugreek treated diabetic rats serum testosterone level revealed non significant decrease from control group . Testis showed partial recovery (fiq.19) .Rats treated with fenugreek recorded significant increase from the control ones. Testis displayed normal pattern (fiq.20). Fenugreek has estrogenic effect (Duke et al., 2002), low levels of dietary phytoestrogen have a biological effect in the testis (Robertson et al, 2002).

Fenugreek seeds are rich in flavonoids (Gupta and Nair, 1999), thus the phenolic structure of fenugreek makes it a radical scavenger for the alternations induced by cytotoxic alloxan.

In conclusion, fenugreek seeds exhibited antioxidant property could ameliorate the alternations induced in diabetes.

This investigation recommended that higher concentrations of debitterized fenugreek seeds may double the regeneration of beta -cells in pancreas, further studies would be done in mammals.

Table (1): Showing the effect of treatment $0.1 \mathrm{mg} / \mathrm{kgBW}$ fenugreek seeds aqueous extract for 4 weeks in body weights, some haematological parameters, blood glucose , insulin and some liver function tests in normal and diabetic rats.

\begin{tabular}{|c|c|c|c|c|}
\hline Groups & Control & Diabetic & $\begin{array}{l}\text { Diabetic treated } \\
\text { with fenugreek }\end{array}$ & $\begin{array}{l}\text { Normal treated with } \\
\text { fenugreek }\end{array}$ \\
\hline $\begin{array}{c}\text { Body weight } \\
\text { Gm }\end{array}$ & $\begin{array}{c}145.83 \\
\pm 4.92 \\
\end{array}$ & $\begin{array}{c}123.33^{*} \downarrow \\
\pm 6.83 \\
\end{array}$ & $\begin{array}{r}140 \\
4.2 \pm \\
\end{array}$ & $\begin{array}{c}155.83 \\
\pm 5 \\
\end{array}$ \\
\hline $\begin{array}{c}\text { R BCs } \\
\times 10^{6} \\
\end{array}$ & $\begin{array}{r}5 . .35 \\
\pm 0.66 \\
\end{array}$ & $\begin{array}{c}2.25^{\star} \downarrow \\
\pm 2 \\
\end{array}$ & $\begin{array}{r}4.5 \\
\pm 0.5 \\
\end{array}$ & $\begin{array}{r}6.2 \\
\pm 0.35 \\
\end{array}$ \\
\hline $\begin{array}{l}\text { W B Cs } \\
\times 10^{3} \\
\end{array}$ & $\begin{array}{l}4.66 \\
\pm 0.6 \\
\end{array}$ & $\begin{array}{l}6.76 \\
\pm 0.8 \\
\end{array}$ & $\begin{array}{c}6 \\
\pm 1 \\
\end{array}$ & $\begin{array}{c}4.6 \\
\pm 0.54 \\
\end{array}$ \\
\hline $\begin{array}{c}\mathrm{Hb} \\
\mathrm{Gm} \%\end{array}$ & $\begin{array}{c}16.33 \\
\pm 1\end{array}$ & $\begin{array}{c}12.5^{*} \downarrow \\
\pm 0.8\end{array}$ & $\begin{array}{r}15.16 \\
\pm 0.75\end{array}$ & $\begin{array}{c}17.33 \\
1.63\end{array}$ \\
\hline $\begin{array}{c}\text { Glucose } \\
\mathrm{mg} / \mathrm{dl}\end{array}$ & $\begin{array}{l}85 \\
\pm 2 \\
\end{array}$ & $\begin{array}{c}280^{*} \uparrow \\
\pm 5 \\
\end{array}$ & $\begin{array}{c}150 * \uparrow \\
\pm 10 \\
\end{array}$ & $\begin{array}{r}79^{*} \downarrow \\
\pm 2.1 \\
\end{array}$ \\
\hline $\begin{array}{l}\text { Insulin } \\
\mu U / d l\end{array}$ & $\begin{array}{l}12.5 \\
\pm 0.5 \\
\end{array}$ & $\begin{array}{l}7.5^{*} \downarrow \\
\pm 0.8 \\
\end{array}$ & $\begin{array}{r}10 \\
\pm 1 \\
\end{array}$ & $\begin{array}{c}14 \\
\pm 0.5 \\
\end{array}$ \\
\hline $\begin{array}{l}\text { AST } \\
\mathrm{U} / \mathrm{L} \\
\end{array}$ & $\begin{array}{c}39 \\
\pm 4.5\end{array}$ & $\begin{array}{l}52^{*} \uparrow \\
\pm 2.3\end{array}$ & $\begin{array}{l}42 \\
\pm 4\end{array}$ & $\begin{array}{c}40 \\
\pm 3.5\end{array}$ \\
\hline $\begin{array}{l}\mathrm{ALT} \\
\mathrm{U} / \mathrm{L} \\
\end{array}$ & $\begin{array}{r}24 \\
\pm 2.5 \\
\end{array}$ & $\begin{array}{l}44^{*} \uparrow \\
\pm 3.1 \\
\end{array}$ & $\begin{array}{r}35 \\
\pm 4 \\
\end{array}$ & $\begin{array}{l}27 \\
\pm 3\end{array}$ \\
\hline $\begin{array}{l}\mathrm{ALT} \\
\mathrm{U} / \mathrm{L}\end{array}$ & $\begin{array}{l}56 \\
\pm 6\end{array}$ & $\begin{array}{l}97^{*} \uparrow \\
\pm 3.4\end{array}$ & $\begin{array}{c}70 \\
\pm 3.8\end{array}$ & $\begin{array}{l}58 \\
4.8\end{array}$ \\
\hline
\end{tabular}


Table (2): Showing the effect of treatment $0.1 \mathrm{mg} / \mathrm{kg} \mathrm{BW}$ fenugreek seeds aqueous extract for 4 weeks in some kidney function tests, cholesterol, triglycerides, total proteins, albumin, globulins and testosterone in normal and diabetic rats.

\begin{tabular}{|c|c|c|c|c|}
\hline Groups & Control & Diabetic & $\begin{array}{l}\text { Diabetic treated } \\
\text { with fenugreek }\end{array}$ & $\begin{array}{c}\text { Normal } \\
\text { treated with } \\
\text { fenugreek }\end{array}$ \\
\hline $\begin{array}{l}\text { Urea } \\
\text { mg\% }\end{array}$ & $\begin{array}{l}22 \\
\pm 2\end{array}$ & $\begin{array}{l}34^{*} \uparrow \\
\pm 1.5\end{array}$ & $\begin{array}{l}28 \\
\pm 1\end{array}$ & $\begin{array}{l}24 \\
\pm 2.5\end{array}$ \\
\hline $\begin{array}{c}\text { Creatinine } \\
\text { mg/dl }\end{array}$ & $\begin{array}{c}0.7 \\
\pm 0.035 \\
\end{array}$ & $\begin{array}{c}1.5^{*} \uparrow \\
\pm 0.05 \\
\end{array}$ & $\begin{array}{c}1.1 \\
\pm 0.05\end{array}$ & $\begin{array}{c}0.8 \\
\pm 0.03\end{array}$ \\
\hline $\begin{array}{c}\text { Cholesterol } \\
\text { mg/dl }\end{array}$ & $\begin{array}{r}128 \\
\pm 4.2 \\
\end{array}$ & $\begin{array}{c}200 * \uparrow \\
\pm 6 \\
\end{array}$ & $\begin{array}{r}140 \\
\pm 3.8 \\
\end{array}$ & $\begin{array}{c}113 \\
\pm 3 \\
\end{array}$ \\
\hline $\begin{array}{c}\text { Triglycerides } \\
\text { mg/dl }\end{array}$ & $\begin{array}{l}50 \\
\pm 7 \\
\end{array}$ & $\begin{array}{c}105^{*} \uparrow \\
\pm 5.7 \\
\end{array}$ & $\begin{array}{r}70 \\
\pm 6 \\
\end{array}$ & $\begin{array}{l}45 \\
\pm 5 \\
\end{array}$ \\
\hline $\begin{array}{c}\text { Total proteins } \\
\text { g/dl }\end{array}$ & $\begin{array}{r}6.5 \\
\pm 0.5 \\
\end{array}$ & $\begin{array}{r}5^{*} \downarrow \\
\pm 0.3 \\
\end{array}$ & $\begin{array}{r}6 \\
\pm 0.5 \\
\end{array}$ & $\begin{array}{r}7 \\
\pm 0.3 \\
\end{array}$ \\
\hline $\begin{array}{l}\text { Albumin } \\
\text { g/dl }\end{array}$ & $\begin{array}{r}3.5 \\
\pm 0.2 \\
\end{array}$ & $\begin{array}{r}3 \\
\pm 0.1 \\
\end{array}$ & $\begin{array}{r}3.5 \\
\pm 0.2 \\
\end{array}$ & $\begin{array}{c}4 \\
\pm 0.1 \\
\end{array}$ \\
\hline $\begin{array}{c}\text { Globulins } \\
\text { g/dl }\end{array}$ & $\begin{array}{r}3 \\
\pm 0.3 \\
\end{array}$ & $\begin{array}{r}2 \\
\pm 0.2 \\
\end{array}$ & $\begin{array}{r}2.5 \\
\pm 0.3 \\
\end{array}$ & $\begin{array}{c}3 \\
\pm 0.2 \\
\end{array}$ \\
\hline $\begin{array}{c}\text { Testosterone } \\
\mathrm{ng} / \mathrm{ml}\end{array}$ & $\begin{array}{c}1.6 \\
\pm 0.02\end{array}$ & $\begin{array}{l}0.71^{*} \downarrow \\
\pm 0.05\end{array}$ & $\begin{array}{c}1.5 \\
\pm 0.06\end{array}$ & $\begin{array}{l}2.5 \uparrow \\
\pm 0.1\end{array}$ \\
\hline
\end{tabular}

Number of rats in each group $=6$

$* \mathrm{P}<0.05$ in comparison to control group

\section{Legend of figures}

Fig.1: Control rat pancreas showing islet of langerhans containing $\alpha, \beta$ and $\delta$ cells. $\beta$ cells are the most abundant cells M.A.F. x 200.

Fig.1a: Control rat pancreas M.A.F. x1000

Fig.2 : Diabetic rat pancreas showing, reduction in the pancreatic $B$ cell numbers, $\beta$ cell vacuolization and necrosis in some surviving $B$ cells $\quad$ M.A.F. $x$ 400.

Fig.2a:Diabetic rat pancreas M.A.F. x1000

Fig.3: Fenugreek extract treatment, showing relatively increasing $B$ cells number M.A.F. x x400
Fig. 3a : Fenugreek extract treated rats

M.A.F. x1000

Fig.4: Fenugreek extract treated diabetic rats showing slight improvement in $B$ cell numbers

M.A.F. $x 400$

Fig. 4a: Fenugreek extract treated diabetic rats

M.A.F. x1000

Fig. 5: Control rat liver showing the normal histological structure of hepatic, with hepatic cords ,hepatic sinusoids and central vein $\quad H \& E x 400$. 
Fig.6 : Diabetic rat liver, showing dilatation and severe congestion of central vein, vacuolization and necrotic area of hepatocytes. Inflammatory cells in the hepatocytes.

$\mathrm{H} \& \mathrm{E} \mathrm{x} 400$.

Fig.6a: Diabetic rat liver, showing dilatation and severe congestion of sinusoids and inflammatory cells in the hepatocytes.

$\mathrm{H} \& \mathrm{E} \times 400$.

Fig.6b: Diabetic rat liver, showing dilatation and severe congestion of portal tract and inflammatory area around it. $\mathrm{H} \& \mathrm{E} \times 400$.

Fig.7: Liver of diabetic rat treated with fenugreek extract, showing ameliorating in the histological structure. $\quad H$ \& E x100.

Fig.8: Normal rats treated with fenugreek extract showing nearly normal appearance of hepatic architecture

$\mathrm{H} \& \mathrm{E} \times 100$.

Fig.9: Kidney of rats in control group , showing normal histological structure of glomeruli and renal tubules $\quad \mathrm{H} \& \mathrm{E} \mathrm{x} 400$.

Fig.10: Kidney of diabetic rats, showing dilatation and severe conge-stion of blood vessels ,diffuse extravagation $\mathrm{s}$ of red blood cells between renal tubules

$\mathrm{H} \& \mathrm{E} \times 200$.

Fig.10a: Kidney of diabetic rats showing glomerular atrophy

$\mathrm{H} \& \mathrm{E} \times 200$.

Fig.10b: Kidney of diabetic rats showing glomerular swelling and tubular degenerative changes H\&Ex400.

Fiq.10c: Kidney of diabetic rats showing glomerular atrophy ,dilated convoluted tubules contain hyaline cast in their lumen

$\mathrm{H} \& \mathrm{E} \mathrm{x} 400$.
Fig.11: Kidney of diabetic rats treated with fenugreek, showing amelio-rated histological structure

$\mathrm{H} \& \mathrm{E} x 400$.

Fig.12: Kidney of normal rats treated with fenugreek extract ,showing normal appearance $\mathrm{H} \& \mathrm{E} x 400$

Fig.13: Aorta of rat in control group $\mathrm{H} \& \mathrm{E}$ x 200

Fig.14: Aorta of diabetic rat showing degenerative changes

$\mathrm{H} \& \mathrm{E} \times 400$.

Fig.14a: Aorta of diabetic rats , showing formation of medial calcinosis

$\mathrm{H} \& \mathrm{E} \times 200$

Fig.15: Aorta of diabetic rats treated with fenugreek extract, showing normal histological appearance

$\mathrm{H} \& \mathrm{E} \times 200$.

Fig.16: Fenugreek treated rats, showing normal pattern $\mathrm{H} \& \mathrm{E} \times 400$.

Fig.17: Testis of rat in control group ,showing the normal histological structure of the seminiferous tubules with different series of spermtogenic layers and spermatozoa H \& E x400

Fig.18: Testis from diabetic rats showing abnormal seminiferous tubules characterized by germ cells depletion as well as sloughing ,degeneration of sperm and debris of spermatogenesis cells could be observed H \& E x 400

Fig.19: Testis of diabetic rat treated with fenugreek extract , showing partially recovery in seminiferous tubules $\quad \mathrm{H} \& \mathrm{E} \mathrm{x} 400$

Fig.20: Testis of normal rats treated with fenugreek for 4weeks showing well developed seminiferous tubules and well developed spermatogenetic activity and leyding cells. $\quad H \&$ E x400. 


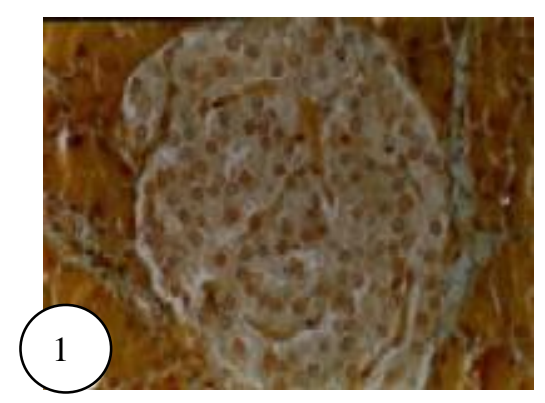

M.A.F X 400

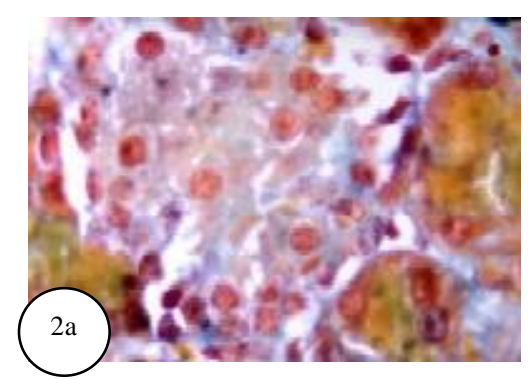

M.A.F X 1000

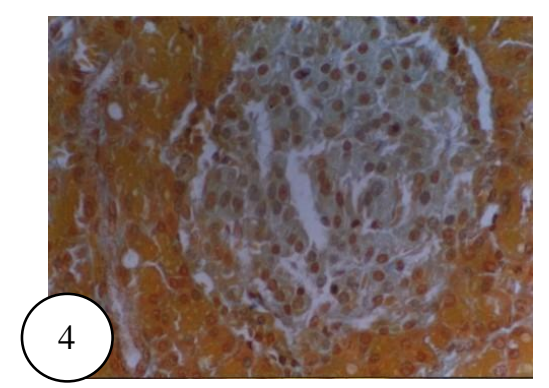

M.A.F X 200

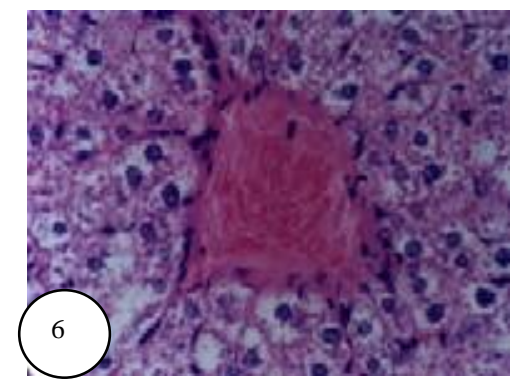

H\&E X 400

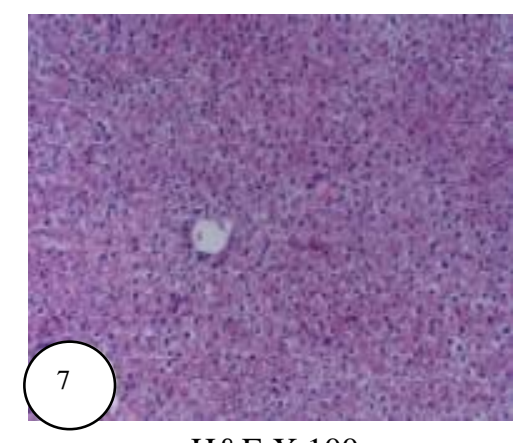

H\&E X 100

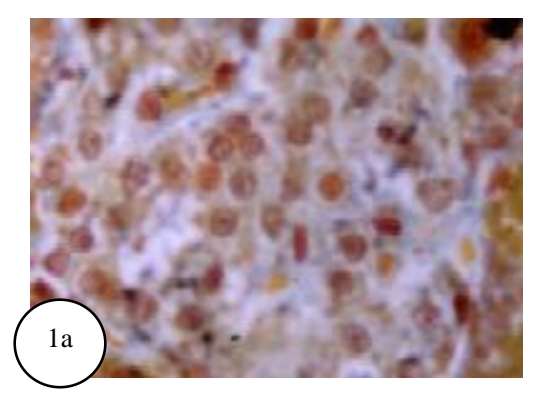

M.A.F X 1000

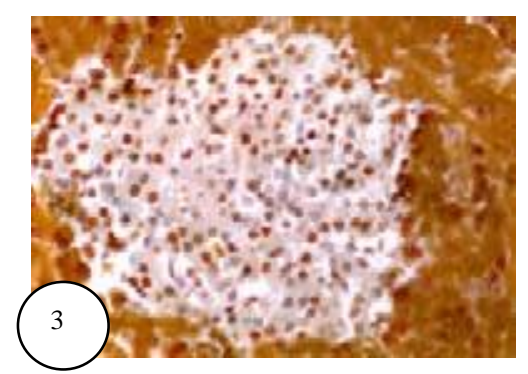

M.A.F X 400

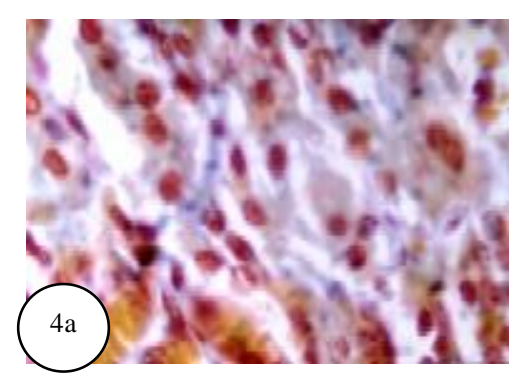

M.A.F X 1000

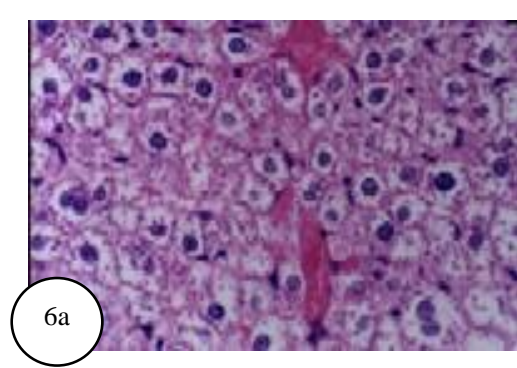

H\&E X

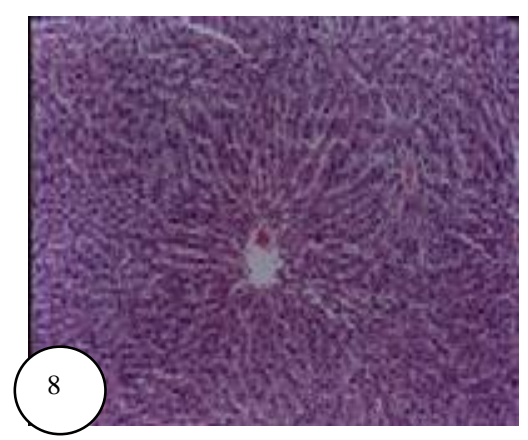

H\&E X 100

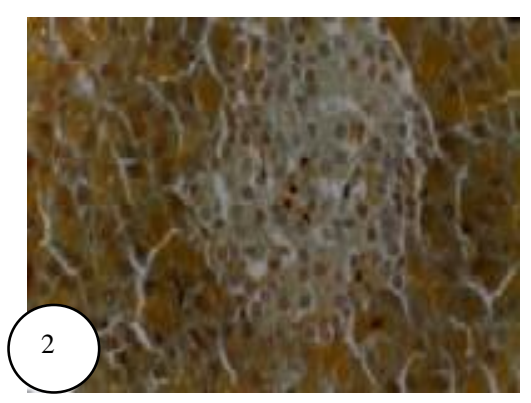

M.A.F X 400

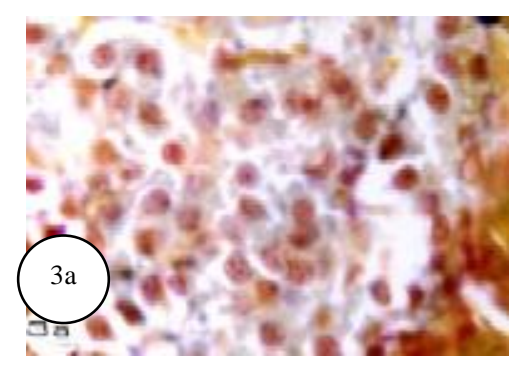

M.A.F X 1000

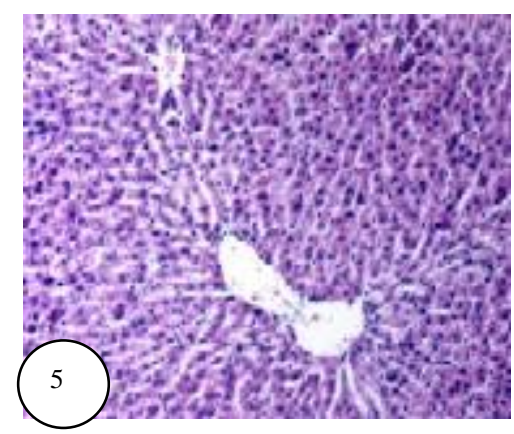

H \& E X 400

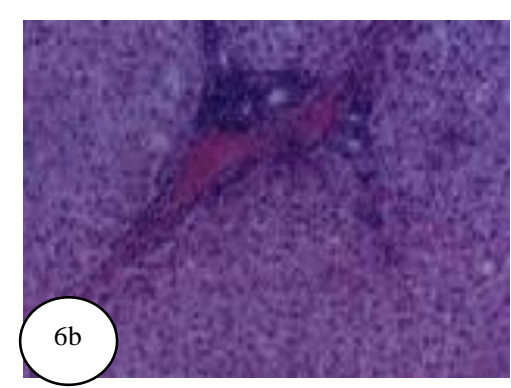

H\&EX 200

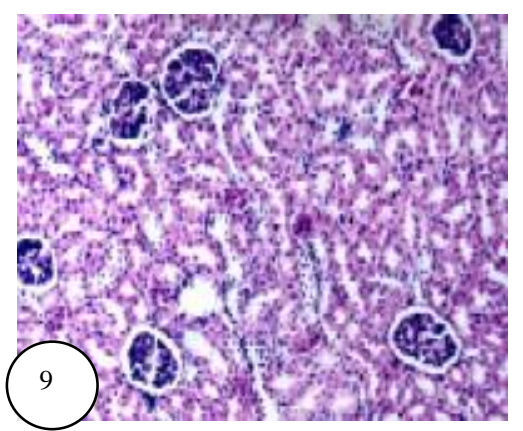

H \& E X 400 


\section{Enas A. M. Khalil}

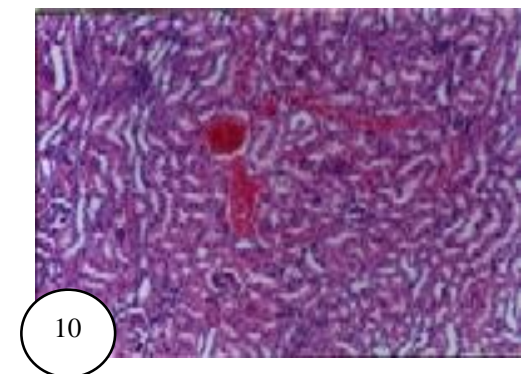

H \& E X 200

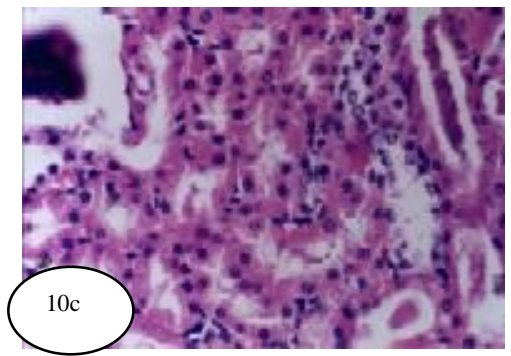

H \& E X 400

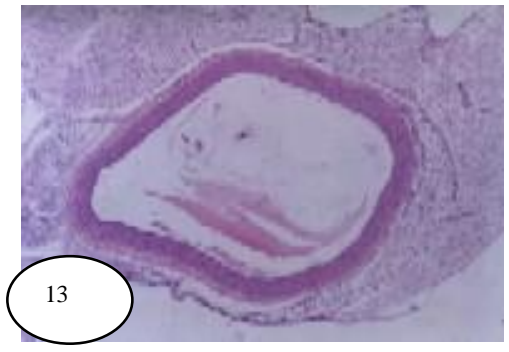

H \& E X 200

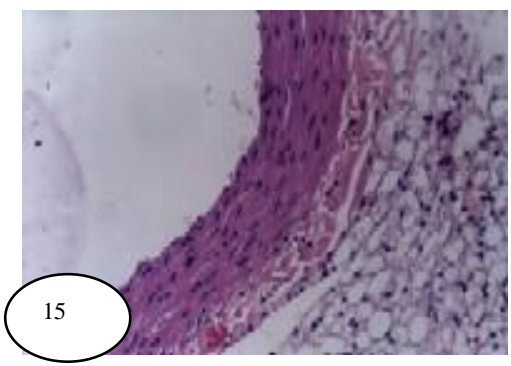

H \& E X 200

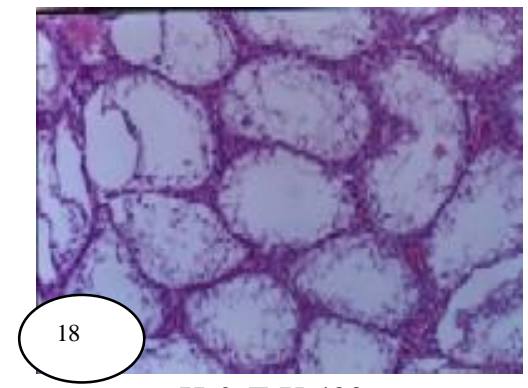

91

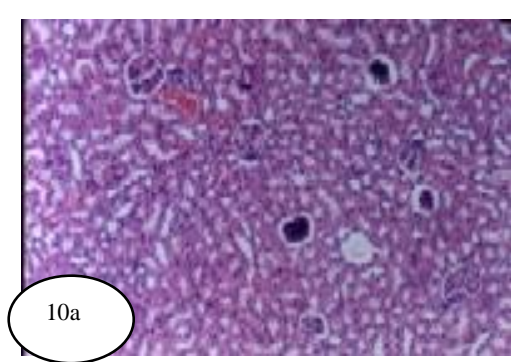

H \& E X 200
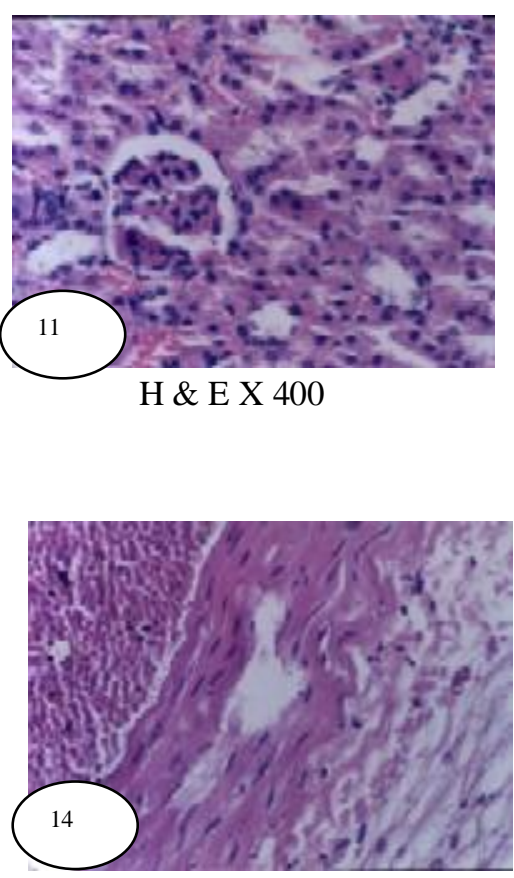

H \& E X 400

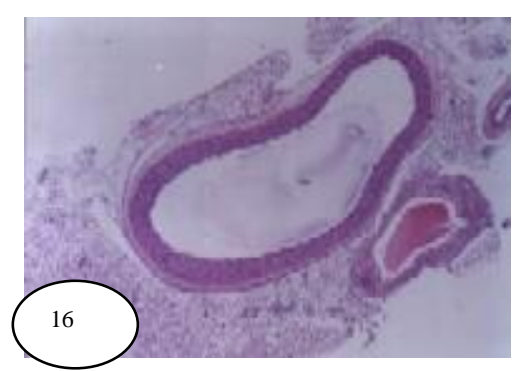

H \& E X 200

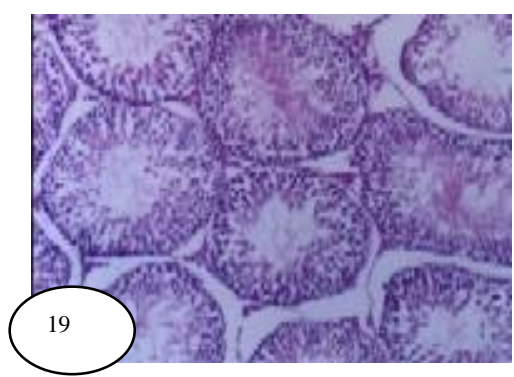

H \& E X 400

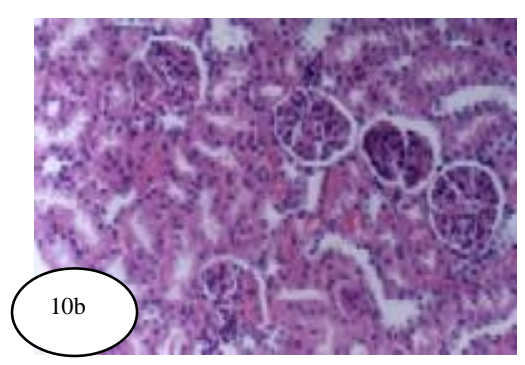

H \& E X 400

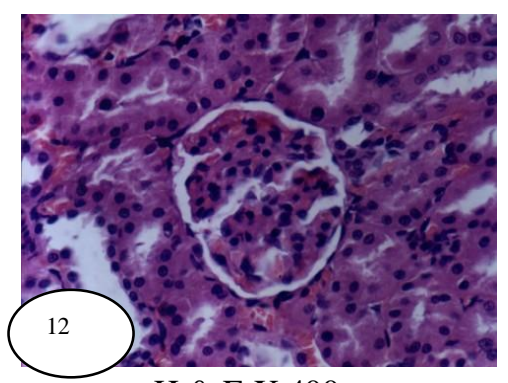

H \& E X 400

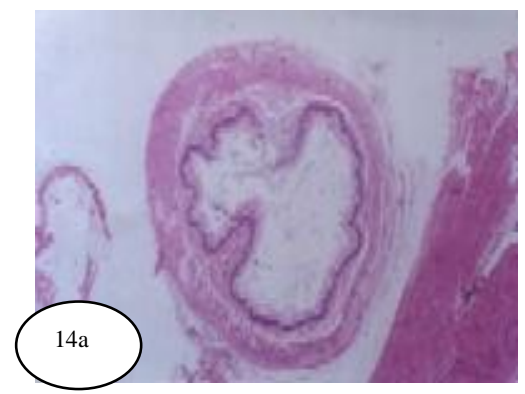

H \& E X 200

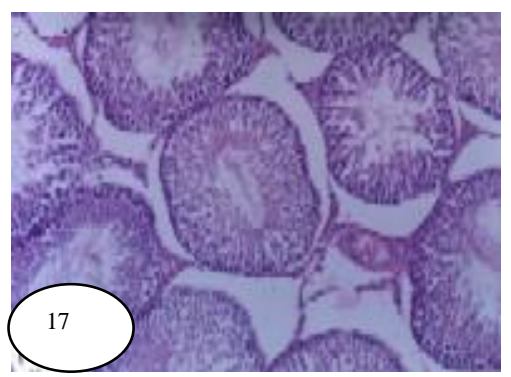

H \& E X 400

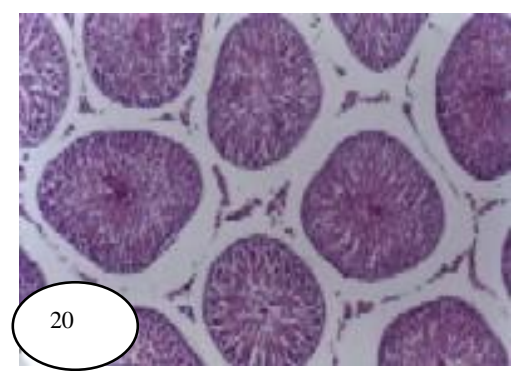

H \& E X 400 


\section{References}

1. Al-Habori,M. and Raman,A .(1998): Antidiabetic and hypocholesterolemic effects of fenugreek [Review].Phytotherapy Research 12,233.

2. Allain,C.C.; Poon,L.S.; Chem,C.S.; , Richamond, W.and Fu,P.C. (1974): Enzymatic determination of total serum cholesterol .Clin ,Chem,20,4.

3. Bartles, H.; Bohmer, M.; Filler G.,Priem F and Lepage, N. (1971):Microdetermination of creatinine. Clin Chem Acta 32,81.

4. Bin-Hafeez, B.; Haque ,R.; Parvez,S. Pandy, S.Sayeed,I and S.Raisuddin(2003): Immunomodulatory effects of fenugreek ( Trigonella foenum graecum L.) extract in mice .Int. Immunopharmacol., Feb (2): 257

5. Blumenthal, M.; Busse, W. and Goldberg, A. (1998): The Complete Commission E Monographs. Therapeutic Guide to Herbal Medicines, Boston ,M.A.: Integrative Medicine Communications ,pp. 130

6. Blumenthal, M.; Goldberg A. and Brinckmann, J. (2000): Herbal Medicine Expanded commission E, Monographs copy right American Botanical Council Published by Integrative Medicine .Communications1029, Chesinut Street, Newton, MA)2464 P.130

7. Bucolo, G. and David, H.(1973): Quantitative determination of serum triglycerides by the use of enzymes .Clin,Chem., 19,476.

8. Bwititi,P.;Musabayane,C.and Nhachi, F.(2000):Effects of Opuntia megacantha on blood glucose and kidney function in streptozotocin diabetic rats J.Ethnopharma.69,247

9. Cornelius,C.E.,(1989): Liver function In:Clinical biochemistry of domestic animals. Jiro Kaneko $4^{\text {th }}$ ed .Academic Press P.364

10. Devasena, T.and Menon, V.(2002): Enhancement of circulatory antioxidants by fenugreek d 1,2 -dimethylhydrazineinduced rat colon carcinogenesis. J.Biochem MolBio,Aug.,6(4) 289.

11. Doumas,B.T.; Waston, W.A .and Briggs, H.I. (1971): Albumin standers and measurements of serum albumin with Bromocresol .Clin .Chem.Acta,31:8

12. Doumas,B.T.(1975):Standards for total serum protein assays .A colloborative study.Clin.Chem.21(8):1159.
13. Duck, J.A.(1985): HandBook of Medicinal Herbs ,CRC Press, Boca Raton ,EL,CRC

14. Duck,J.A.; Codwin, M.J.,and Cillier, J.(2002):Hand Book of Medicinal Herbs CRC press P.296

15. Finco,D.R (1984): Kidney function In :Clinical diagnosis and management by laboratory methods .Henry ,J.B. editor $\left(17^{\text {Th }}\right.$ edition $)$ W.B.Saunders .company Philadelphia.p.441.

16. German Society for clinical chemistry (1972): Standard method for clinical chemistry ,standard method for determination of alkaline phosphatase (ALP)activity J.Clin.Chem.Clin.Biochem,0, 290

17. Gondos,B.and Bevier,W.(1995):Effect of insulin on testicular alternations in the nonobese diabetic mouse .Ann.Clin. Lab. Sci, 25:272.

18. Gupta, R.and Nair, S. (1999): Antioxidant flavonoids in Indian diet .South Asian J.Prev Cardiol. 3:83 Haefele, C.; Bonfils,C.and Sauvaire,Y. (1997): Characterization of a dioxygenase from Trigonella foenum involved in 4-hydroxy isoleucine biosynthesis .Phytochemistry $, 44,563$

19. Joy, K.L. and Kuttan, R.(1999):Antidiabetic activity of Picrorrhiza kuroa extract .J. Ethnopharama. 167,143.

20. Jefferson ,L.S.;Warren,S.L;Peavy .D.E.; Miller, J.B.;Appel,M.;Taylor T.M.(1983)

: Diabetes induced alternations in liver protein synthesis : Changes in the relative aboundance of mRNA for albumin and other plasma proteins.

21. Kaneko, J. (1989):Clinical Biochemistry of Domestic Animal $4^{\text {th }}$ ed.Academic press,inc.New York,London Tokyo

22. Kang-Xin;Fang-Yunzhong;Xin-Wanjuan and Sunchunr ,P.U.(1990): Observation on the effects of irradiation in vitro and in vivo on the SH-group of rat erythrocyte membrane by spine lable technique.j.Rad.Res.Rad.process,8(2):103

23. Kapoor, L. D.(1990): Handbook of Ayurvedic Medicinal plants ,CRC Press Boca Raton, fl

24. Kiernan,J.A.(1999):Histological and histochemical Methods. Theory and Practice $3^{\text {rd }}$ ed P.161.Printed in Great Britain by the both Press, Somerest.

25. King,G.L.;Kosinski,E.and Kwok,c. (1990): Cardio-vascular complications of diabetes. In:Principle and practice of endocrinology and metabolism by Becker ,K. J.B. Lippincott company p.1127 
26. Paget, G. E. and Barnes, J.M.(1964):"In toxicity tests" Vol.(1). Chapter (6) P.135, Editor: Laurance, D.R. and A. L. Academic Press, London, New York.

27. Pandian, R.S. ;Anuradha C.V. and Viswanathan, P.(2002).:gastroprotective effect of fenugreek (Trigonella foenumg graecum ) on experimental gastric ulcer in rats .J.Ethnopharma.;Aug,81(3):393.

28. Puri, D.;Prabhu, K.M.; Murthy, P.S.(2002): Mechanism of action of a hypoglycemic principle isolated From fenugreek seeds. Indian J Physiol Pharmacol . Oct;46(4):457

29. Ravel, R.(1984): Renal function tests .In: Clinical laboratory medicine .Clinical application of laboratory data $4^{\text {th }}$ ed. Year Book Medicalpublishers,Inc.P.129

30. Ravikumar,P. and Anuradha C.V. (1999):Effect of fenugreek seeds on blood lipid peroxidation and antioxidants in diabetic rats.PhytotherRes.May;13(3):197

31. Reitman ,S. and Frankle,S.(1957) : A colorimetric method for determination of serum glutamic oxaloacetic and glutamic pyruvic transaminases .Am. J. Clin Path.28:56

32. Robertson, K. M.; O'Donnell, I. L. ;Simpson, E.R. and Jones, M.E. (2002): The phenotype of the aromatase knockout mouse reveals dietary phytoestrogens impact significantly on testis function .Endocrinology Aug; 143980;2913

33. Sendecor, G.W. and Coebram, W.C.,(1969): In "statistical Methods " $6^{\text {th }}$ ed Iowa State Univ. Press Anes, Iowa, U. S.A. P.70

34. Sharma, R. D. ;Raghuram, T.C. and Rao, N.S.(1990):Effect of fenugreek seeds on blood glucose and serum lipids in type I diabetes. Eur. J. of clin.Nutr.44,301.

35. Sharma, R. D.; Sarkar A. and Hazara D.K. (1996): Use of fenugreek seed powder The management of non-insulin dependent diabetes mellitus Nutrit.Res.,16(18)1339.
36. Sharma R.D.,Sarkar DKand Hazra B(1996): Hypolipidaemic effect of fenugreek Seed Chronic study in non insulin dependent diabetic patients. Phytother; $1: 334$.

37. Shang, M.;Cai, S.;Han,J.;LLi.J.; Zhao,X.; Zheng, J.;Namba, T.; Kadota S.;Tezuka, Y.and Fan,W. (1998): Studies on flavonoids from fenugreek (Trigonella foenumg graecum L.).Zhonggue ZhongYooZaZhi.Oct.,23(10):614-639.

38. Sur, P.;Das, M.;Gomes, A.;Vedasiromoni, J.R.;Sahu, N.P., Banerjee, s; Sharma R.M.;Ganguly, D.K.(2001): Trigonella foenumg graecum (fenugreek) seed extract as an anti neoplastic agent. Phyto Ther. Res.May;15 (3):257

39. Tabacco,A.; Meiattini, F.; Moda, E. and Tarli P.(1979): Simplified enzymatic /colorimetric serum urea nitrogen determination .Clin. Chem.Feb.25,(2):336.

40. Tanaka,K.;Nanbara,S.;Tanaka,T;Koide, H. and Hayshi,T.(1988): Aminotransferase activity in liver of diabetic mice. Diabetes Res. Clin.Pract.,5(1):71

41. Tarleton ,G.W.;Gondos,B. and Fomby ,B.(1990): Testicular alternations in nonobese diabetic mouse.Endocr.Pathol., 1;85.

42. Tiran, D.(2003): The use of fenugreek for breast feeding women .Complement Ther. Nur. Midwifery;Aug.,9(3) :155

43. Thirunavukkarasu V., Anuradha C., and Viswanathan P.(2003): Protective effect of fenugreek (Trigonella Foenum graecum ) seeds in experimental ethanol toxicity J.Ethnoph.3,APR.80(30):237

44. Thompson Coon J.S. and Ernst, E.(2003): Herbs for serum cholesterol reduction : a systemat Fam. Pract; Jun,52(6):468

45. Trinder,P.(1969): Determination of glucose in blood using glucose oxidase with an alternative acceptor .Ann. of Clinc.Biochem.6,24 


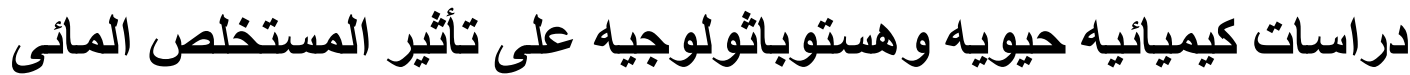

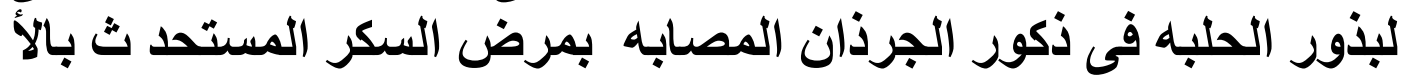 لوكزان
}

\author{
أيناس على مهاى خليل \\ الهيئه القوميه للرقابه و البحوث ملثي الدو ائيه
}

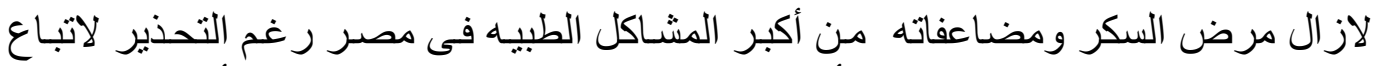

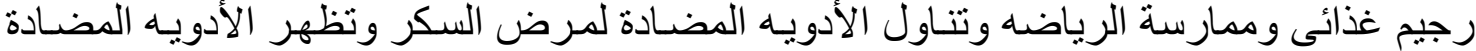

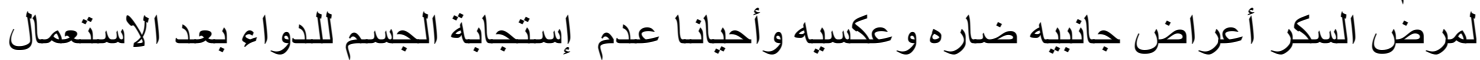

ويرجع مـرض السكر الي نقص هرمون الأنسولين و هذا يؤدى الى أضطر اب العمليـات لفترة طويله

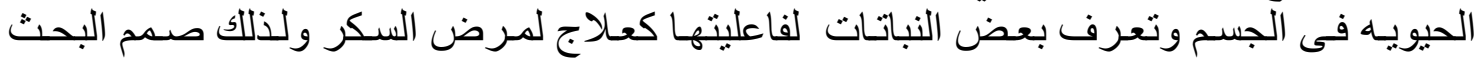

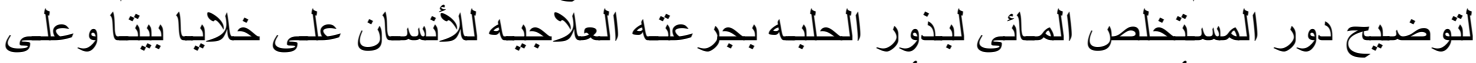

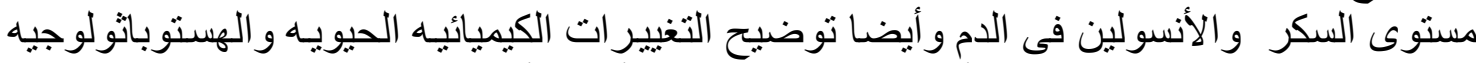

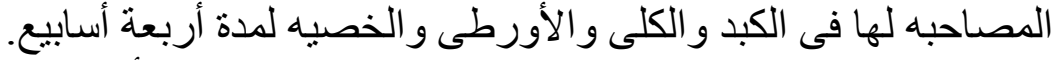

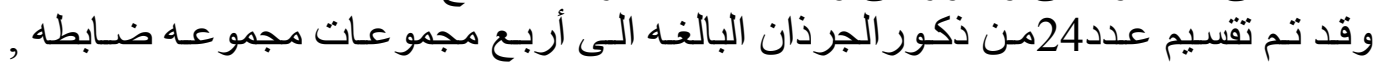

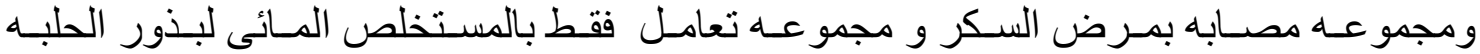

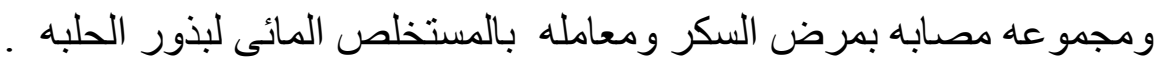

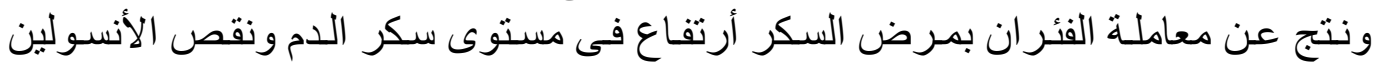

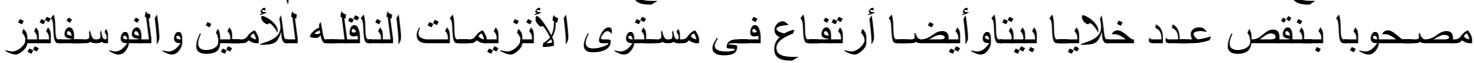

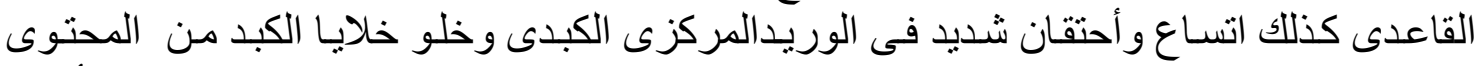

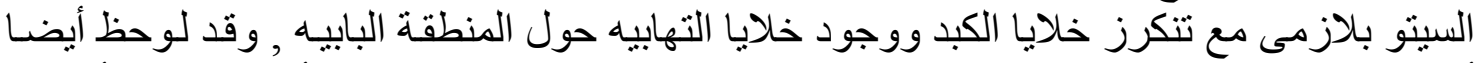

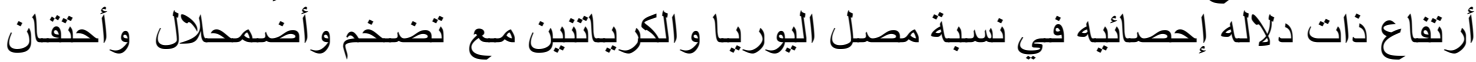

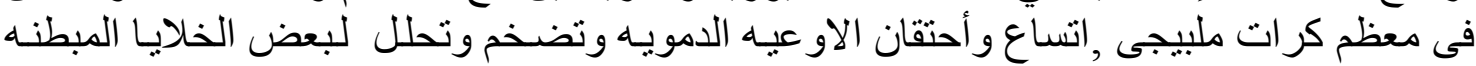

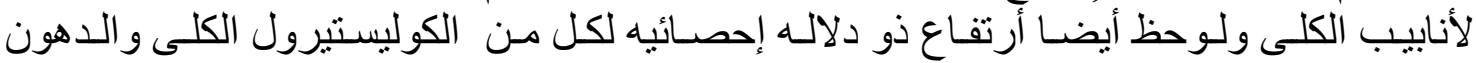

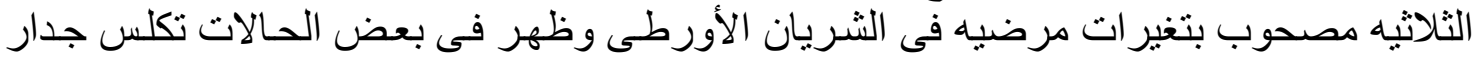

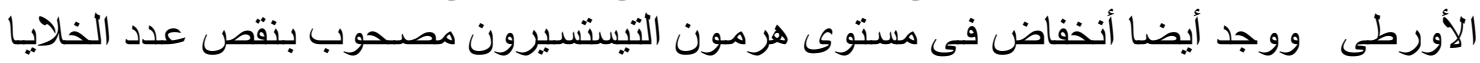
الجرثوميه وكذللك موت كثير من الحيو انات المنويه

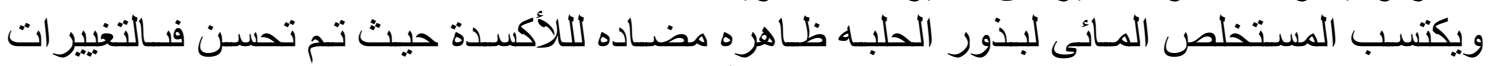

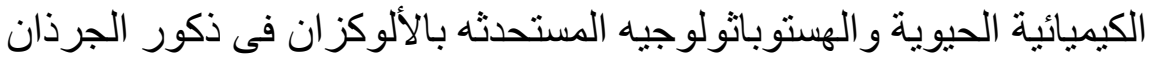

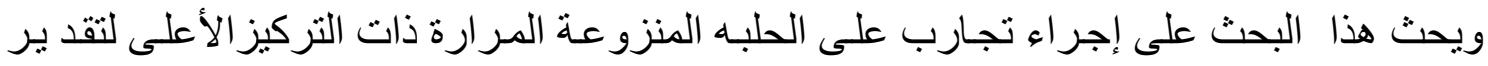

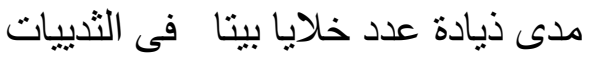

